\title{
Rapid diapir growth, a triggering agent of a $61 / 2$ magnitude earthquake on October 29, 1966, in Acarnania (Greece)
}

\author{
A. G. Galanopolzos - A. Froxomides *
}

Received on July 28th, 1973

\begin{abstract}
Sumary. - There exists good evilenee that diapir growing oeeurs at a rate similar to the rate of sedimentation. Taking this into account, it is reasonable to assume that differential, rapis loaling, during the filling of the Kremasta reservoir, combined with a deeper penetration of fluids, may have affected the largre-scale deformation of the Triassic strata of gypsum in Aeamania and probably increased diapir growth at a catastrophic rate; consequently long-term stability of the diapiric formations of gspsum disturbed by exeessive deformation may have resulted in a premature re. lease of the regional strains in the form of a very shallow earthruake on Oetober 29, 1966.

Riassunto. - Esistono buone testimonianze elhe laecrescimento del diapiro avvenga con una velocita pari a tuella di sedimentazione. Partendo da questa premessa, è regionevole presumere ehe limprovviso earieo, a seguito sel riempimento clel bacino di Kremasta, sommato ad una più profonda penetrazione di liquidi, possono aver contribuito alla deformazione di grandi proporzioni subita dagli strati Triassici del gesso in Acarnania e probabilmente aver aumentato in modo catastrofico la velocita di accrescimento del diapiro; di conseguenza la lunga stabilita delle formazioni diapiriche di gesso disturbate da ecessiva deformazione, possono aver pro. vocato una prematura liberazione delle tensioni regionali sfociata quest'ultima, il 29 Ottobre 1966, sotto forma di un terrenoto molto superficiale.
\end{abstract}

It is rather well established and generally accepted that many triggering forces of relatively small magnitude, in comparison with the main deep-seated strain jroducing forces, may change under certain favourable conditions the rate of strain release in a stressed region being close to breaking strength (3).

(*) National Otservatory of Athens. Scismologieal Institute, Athens (Grece). 
After a long larek or complete absence of alestructive slocks in the westem part of central Greece an musual eartluquale activity started in the Kirmasta dam area abont three mout lis after impounding of the artificial latie (1945, July 21) in the area of the Gavoro zome. The activity rulminated in these $61 / 4$ to 6 1/2 manitude shocks on February 5, 1966, October 29, 1966 ancl May 1, 196iт.

The Gavjovo massil forms a fauleal anticline with NXVT-SSE rumbing axis belonging to the Gavovo - Tripolis zone; it consists of

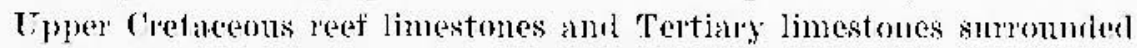
by flyseh deposits. On evielence of the "Institut Frangais du Petrole" (I.F.P., 1966), quoted by Ricliter auri Mariolakos (s), the ca. 1000 m

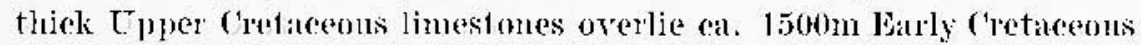
and Jurassio limestones and a Triassic formation of a salt cushion (gypsum, anlyylyite aud dolomile) of unlinown thickness (s. Fig. 1).

At the beginning of the flyseh ileposit ion in the Ionian and Gavoro zone at the Epper Eocene this area represented an uplift, flat was covereal with the liysch not before the oligocene. Aceording to J). Rich-

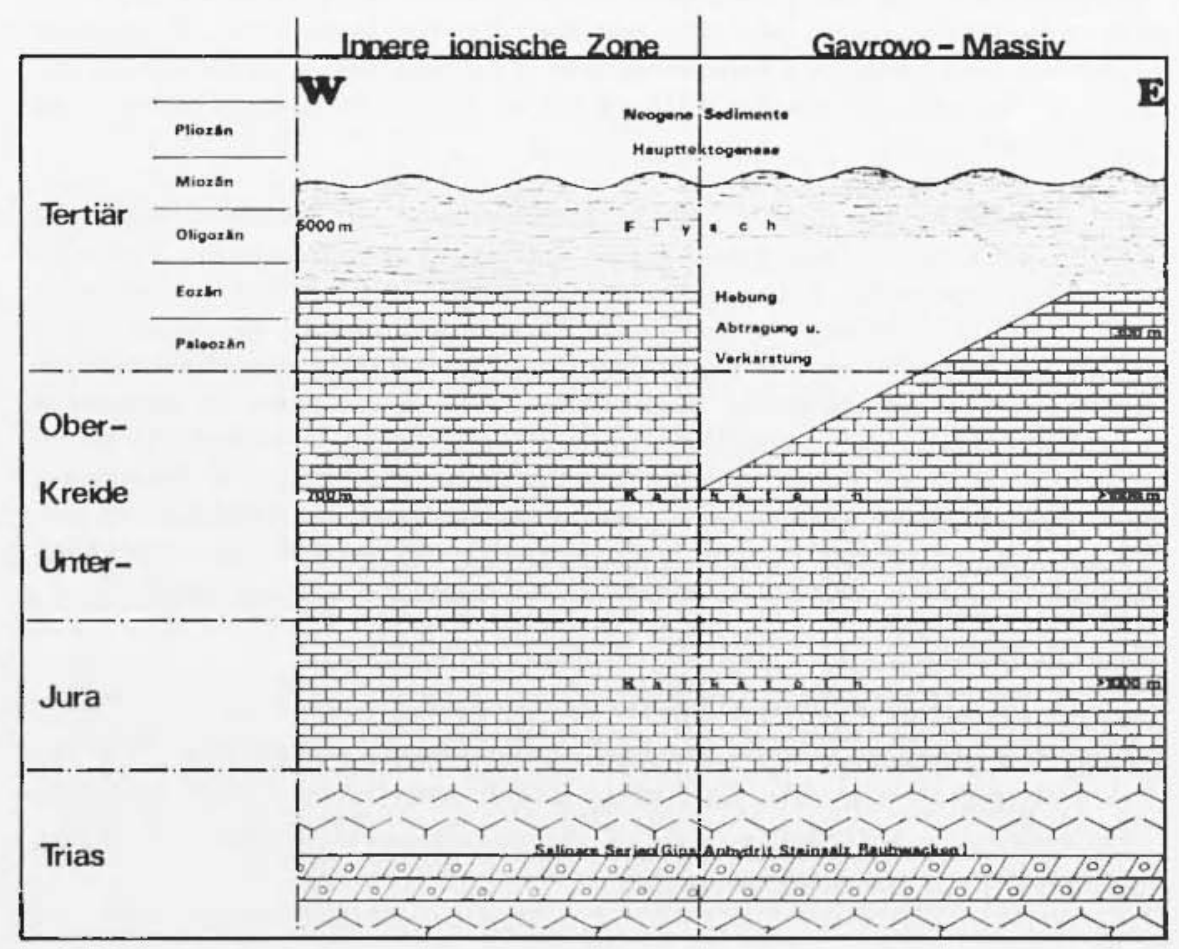

Fig. 1 - Stratigraphy of (iavrovo zone and inner Ionian zone after Dieted Ricliter ant llias Marislalios $\left({ }^{5}\right)$. 
ter and T. Mariolakos (5) the "plift movement wats cansed by halokinesis (s. Fig. 2), problucing numerous faults that strike nearly parallel to the direction of the Gavrovo anticline. The same tedonic avolution was put forward by A.G. Yignie ${ }^{(8)}$ for the Comarillas gorge in spatin.

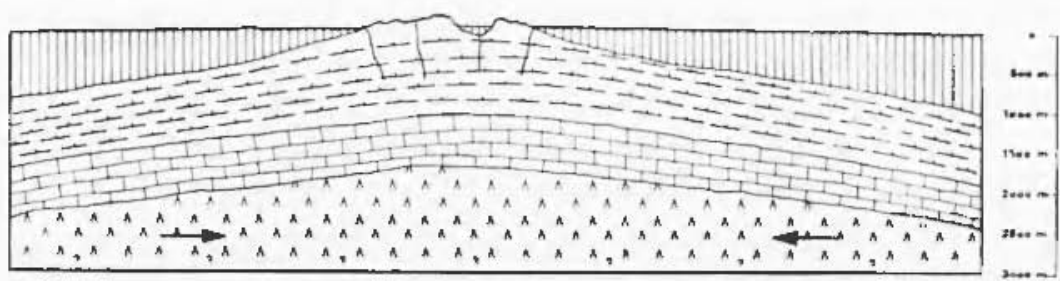

b
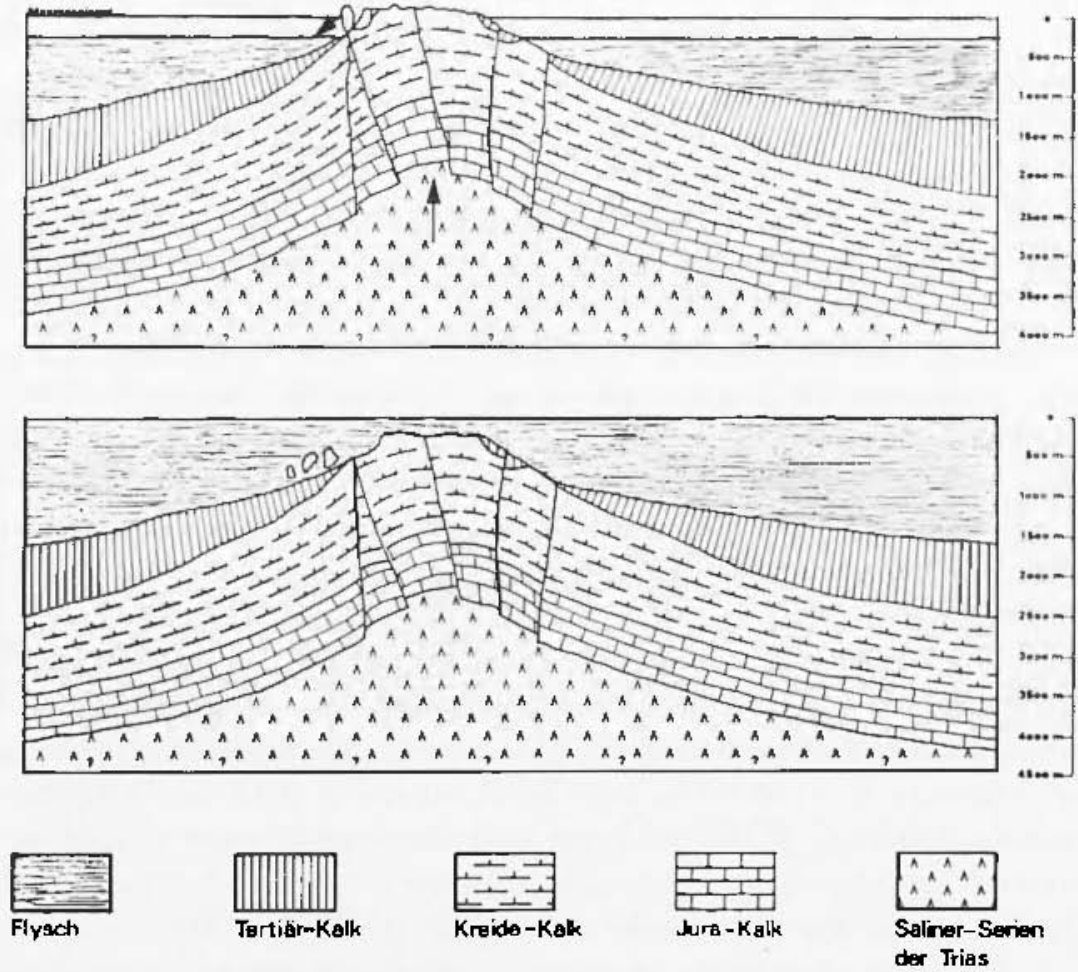

Wige. 2 - Sehematic dianram showing the uplift process of Gavrovo Massif after Dieter Riehter anul Ilias Marioliaks ( $\left.{ }^{5}\right)$ :

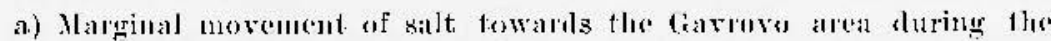

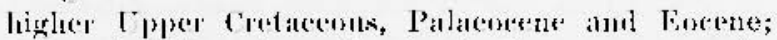

b) Formation of at salt cushion in the fatwovo area and ateselerated upiaft at the begrimning of figseh deposition, bretaking oll of huge fragments:

c) Diminution of uplift and cqualization of the relief in the olignesene. 
There exists good evirlence that rliapir growing oceurs at a rate similar to the rate of sedimentation (4). Taking this into account, it is reasonable to assume that diflerential, rapirl loading, during the filling of the Kremasta reservoir, combined with a deeper penetration of fluids, may have aftected the large-scale deformation of the Triassic strata of gypsam in Aearnania and probably increased diajur growtl at a catastrophic rate; consequently long-term stability of the diapiric formations of gypsum disturber by excessive deformation may have resulted in a premature release of the regional strains in the form of a very shallow eartliquake on Oetober $29,1966\left(38.9^{\circ} \mathrm{X}, 21.1^{\circ} \mathrm{d}\right.$; $\left.h=1 \pm 5.5 \mathrm{~km}, M_{s}=61 / 2\right)$. The restriction of the highest intensity (VIII) to just one locality (Katomna) speaks well for the shallowness of the foeus.

A similar easc, well flocumented, was observerl at the dam site in the Camarillas gorge, Spain, December 8, 1961, and presumably at the dam sites of Canelles-Santa Anna, Spain, June 9, $1962\left({ }^{\circ}\right)$ and also at the ram site of Oued Forlsa, in Algeria, from January to Nay $1933\left(^{6}\right)$. There is evirlence in sprectacular fashion that movement of the salt is even now affecting the uppermost secliment layers at the sea floor of western Merliterranean (7).

lisutheukes triggered by water loaling and/or lubrication are in gencral associated with normal faulting; this was the case of the Kremasta eartliquake on February $5,1966\left(39.1^{\circ} \mathrm{N}, 21.7^{\circ \mathrm{E}} ; h=16 \pm 4.7 \mathrm{~km}\right.$, $\left.M_{\mathrm{s}}=61 / 4\right)$. The Katoma eartliquake of Ootober 29,1966 , was associated with thust faulting (s. Fig. 3); this is in accordance with that one should expect if rapid diapir growth has acted as triggering mechanism (s. Fig. 4).

The epicenter of the second late aftershock of May $1,1967\left(39.6^{\circ} \mathrm{N}\right.$, $\left.21.3 \circ \mathrm{F}, h=34 \pm 3.2 \mathrm{~km}, M_{s}=6.1 / 2\right)$ and that of Oetober 29, 1966 , are almost equidistant from the epicenter of the Kremasta earthquake of February 5, 1966. The fault meelinnisms of both late aftershocks were similar, i.e. of reverse type; it is then possible the evaporites to extend northwards and the same triggering agent to have also acted in the ease of the Drosopegle eartliquake of May 1, 1967.

The rate of diapiric processes is relatively greater when diapirs are approaching or reaching the surface (s. Fig. 4); thus the rate of movement of evaporites at far greater deptil should be markerly less than the rate of growtl of a well-keveloped diapir approacling the surface. This might explain, at least to some extent, wliy the progressive, jerky relief of the regional stress field was manifested disastrously 


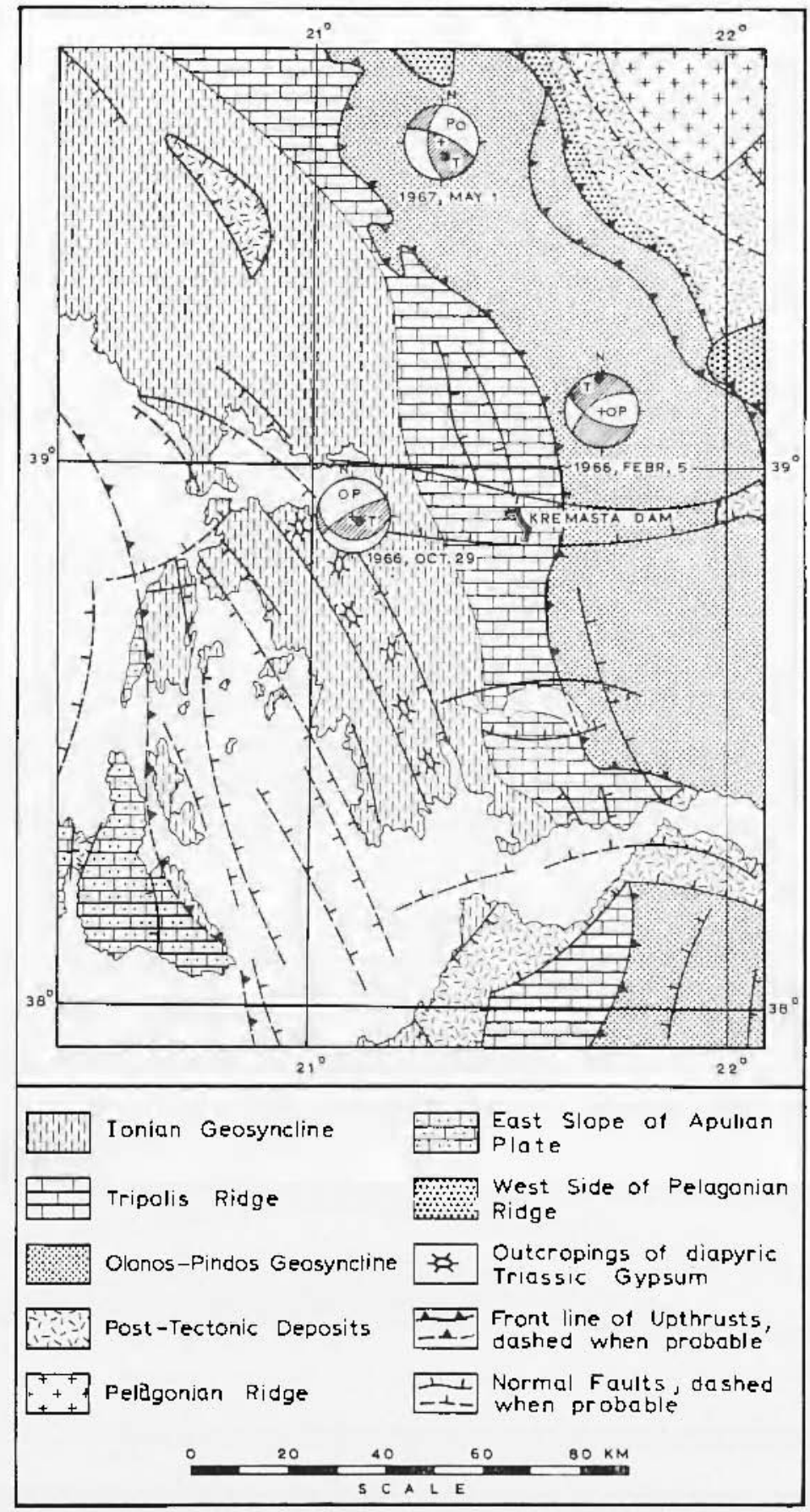

Fig. 3 - Struetural lineaments $\left({ }^{1}\right)$ and fault .. plane solutions tor the main earthquake of 1960, Febs. 5 , and the two late aftershocks of 1966 0et. 29 and 1967 , Nay I $\left({ }^{2}\right)$. The focal mechanisms are shown as equal-area projections of the lower focal henisphere. The open eireles are the axes of compression, $P$, and the closed circles are the axes of tension, $T$. 

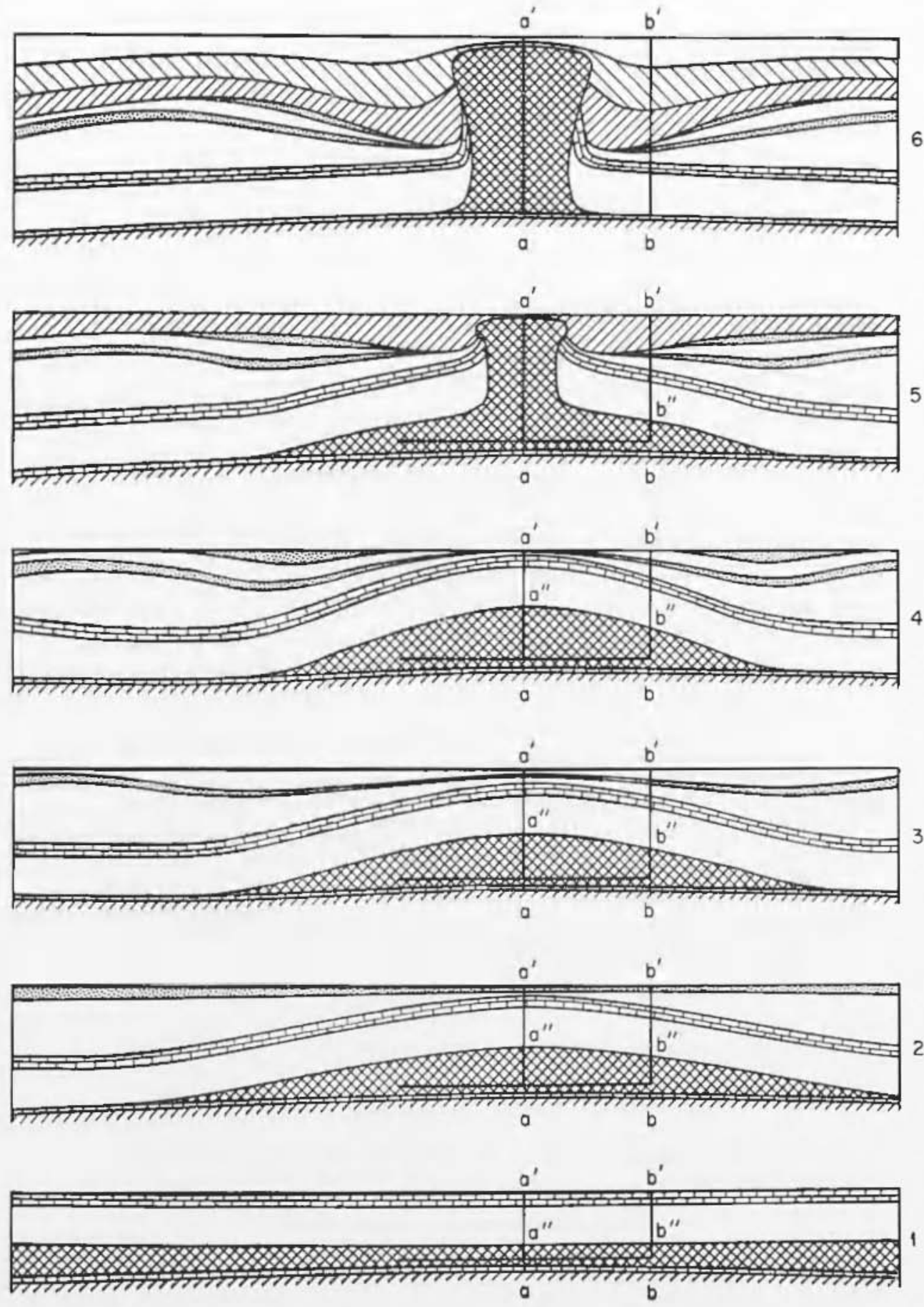

Fig. 4 - Diagramenatis: development of a salt strueture after Ferrecero (ibka (1). 


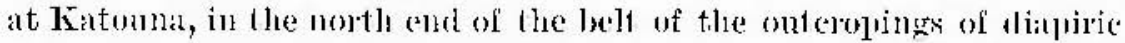

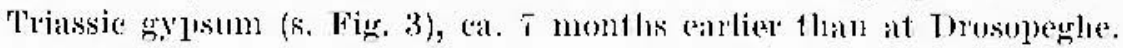

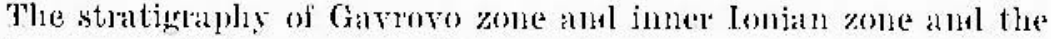

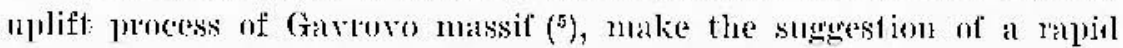
sliapir growll being responsible for the reliof of the regional stress field more certain. The idea is corroborated by the loresence of many warm sulphureuns springs in the area comsislered; the existence of

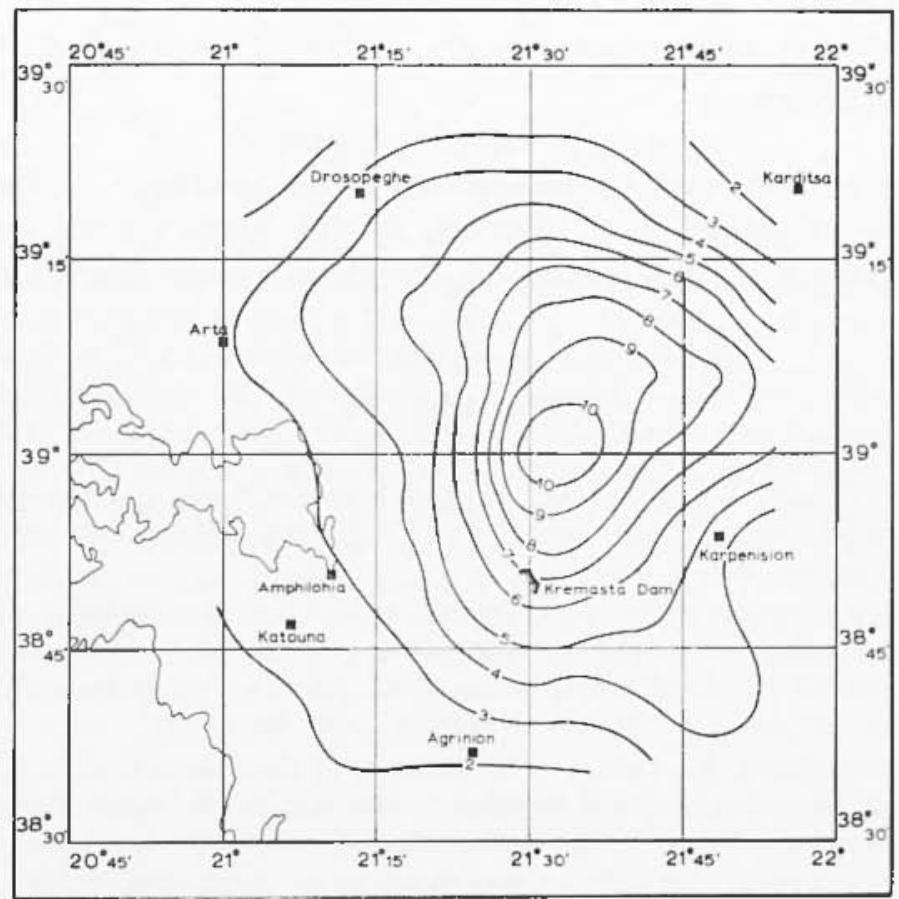

Fig. 5. - Map slowing earthquake density over a 7.year period, 1964-1970, after two iterations. Density is measured as the number af erents per 0.10 latiluale-lomgitude reetangle.

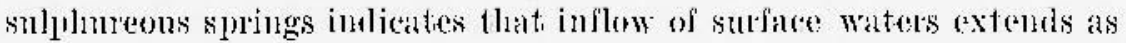
reep as the 'Triassice gypsim layer at least. It slowid be arleded that sulphurems springs have been closed churing the construction of the Fremasta dam. This also must have contributal to the clange of the stress distribution patten in the region consideresl.

The $61 / 2$ magnitude earliqualies on Octolues 29, 1966, and an May 1,1967 , hawing ocenred in the afterslock period started by the 
Kremasta earthouake on February 5, 1966, on the outskirts of the 1064-19-0 arthquake ilensity zone (s. Fig. 5), reveal their interplay and close connection; thus the label "late aftershocks" we have put on them is well justifiell.

The center of the earthouake density pattern over the $\mathbf{i}$-year period, 1964-1970, is close to the instrmmental epicenter of the Kremasta. earthquake, i.e. abont $18 \mathrm{~km}$ to the North of the Kremasta dam. Locations and focal depths for all earthqualies are those given by I.S.O.

\section{MOKXOWLEDGHENTS}

The authors wisl to acknowledge their gratitude to Prolessor J. Rotles for ealling their attention to the Yagie's work and providing them witl photocopies of Gourinard's and Yagüe's papers.

\section{RWELRESES}

(1) Borxovas, J., Gatanopoulos, A. and Deirisasis, N., 1971. - Seismotectomic Map of Greece. "Iubl. Scism. Iust. Nat. Obs. Athens and [ust. (ieol. subsurfact. Res.", Greece.

(2) J)rakopoulos, I. and Delibasis, X., 1973. - On the Ifeohanism of some Earlhatates in the dren of If estern Greece and the Stress Producing Them. Presconted in the Furop. Serisur. Com, Mecting at Brisos, Romania 1972; in press in "Technical studies", 10, Bururest.

(3) GaLanopocios, A., 1966. - The Infuence of the Fluctuation of Warahom. Lahe Elevation on Loeal Earthquake Activity in the Altira Basin Irea. "Auu. Grool. Pays Jlellen.", 18, 281-306.

(") Cirnd, F., 1972. - Review of Sall Teetonies in Relation to the Disposal of Radioantine Wastes in Sall Formations. "Geol. Soe. Ant. Bull.", 83, 12, $3551-3574$.

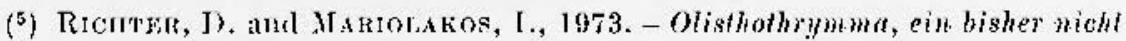
bekanntes tekto-sedimentalogixehes Phaenomen in Flyseh-1biagerngen. "N. Jh. Geol. Paliiont. Abh.," 142, 2, $165-170$, Stutitgat.

(9) Rotrte, P'. J., 1970. - Seismes Arfificiels. "f'ectonophysies", 9, 215-238.

(7) STaxis, J. D., 1973. - Modern Basin Sedimen Deformation by Sall Teetonies, Hestern Medilerromern. Abstacts, Furopean Geophysical Suciety, Zürich, September 25-29, 1. 97.

(") Yatï: G, G. A., 1969. - Miero-Earhquakes in Resereoirs. "Procecdings of of the Joint Symponim of RCCE/AEIS, Second Furojean Symposinu on Farthquale Fingineering", Mineographed, Madrid, plp. 26-35.

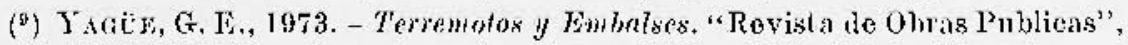
PP. $743-760$. 